\title{
Application of public-private partnership mechanisms for competitive growth of inland water transport in Russia
}

\author{
Elena Voskresenskaya ${ }^{1 *}$, Lybov Vorona-Slivinskaya ${ }^{2}$ and Tatyana Ponomareva ${ }^{3}$ \\ ${ }^{1}$ Peter the Great St.Petersburg Polytechnic University, 195251, St. Petersburg, Polytechnicheskaya \\ str., 29, Russia \\ ${ }^{2}$ Saint Petersburg State University of Architecture and Civil Engineering, 190005, St. Petersburg, 2nd \\ Krasnoarmeyskaya St., 4, Russia \\ ${ }^{3}$ Admiral Makarov State University of Marine and Inland Shipping, Saint-Petersburg, Dvinskaya st., \\ 5/7, 198035, Russia
}

\begin{abstract}
The article deals with urgent problems of transport system development in Russia, paying the particular attention to inland waterway transport. The research is focused on the investment in the development of road infrastructure and methods of investing transport projects using publicprivate partnership mechanisms. The main reasons constraining the development of inland water transport in Russia are the insufficient amount of funds contributed to the development of the industry and their occasionally unreasonable use. In recent years, the world trend is to attract not only owners, but also infrastructure users to finance the inland waterway transport industry at a time when the financing gap is significant. The authors concluded that the simultaneous implementation of measures combining the introduction of fees paid by user and involving the improvement of water transport infrastructure through the public-private partnership mechanisms would promote attracting additional sources of investment. These investments will help to accelerate the industry modernization and implement the innovative scenario for the development of national economy. The authors developed the new model of state policy on attracting extra-budgetary sources of financing to the inland waterway transport industry.
\end{abstract}

\section{Introduction}

The need for the elaborated, reliable and modern transport infrastructure is a particularly relevant issue in Russia. Today, the country is experiencing significant restriction of the economy progress due to insufficient development of the transport system. The prevailing conditions demand the more active use of natural communication routes, such as rivers. The development of inland waterway transport can reduce the load of land transport modes such as automobile and railway and enable implementing the main advantages of ship traffic including low cost of transportation, environmental friendliness and safety.

\footnotetext{
${ }^{*}$ Corresponding author: elenvoskr@mail.ru
} 
The adverse influence of deep deterioration and obsolesce of the whole complex of waterway technical equipment on the stability and efficiency of inland water transport sector leads to the decrease in its potential. The reason is insufficient amount of financing of the industry during the last decades. Application of modern forms and methods of attracting investments is capable to change this situation and provide the demanded level of rehabilitation of fixed assets belonging to inland water transport in Russia. The industry does not fully use the mechanism of public-private partnership that could allow the government to attract extrabudgetary sources of investment while maintaining control over strategically important facilities of transport infrastructure.

Issues of investment in transport were considered in the works of authors: Belitskaya A., Varnavsky V. G., Klymenko A. V., Korolev V. A., Litovchenko S. E. Korsakova M. I., Kachalov R. M., Reznichenko V. [1-5]. Earlier, the authors of the present article paid particular attention to the evaluation of economic efficiency when considering public-private partnership projects [6-17]. The application of a new methodology for assessing the effectiveness of public-private partnership projects resulted in the necessity of investigation of its features.

\section{Materials and Methods}

Today, the issues of financing the inland water transport of Russia are given more attention than earlier. In 2016, the "Strategy for the development of inland water transport of the Russian Federation for the period up to 2030" was approved by the order of the Government. Moreover, if the main share of expenditures in the preliminary Strategy (from 52\% to 59\% depending on the scenario chosen) accounted for the federal budget, then the adopted document implies the more active involvement of extra-budgetary funds: the federal budget expenditures will amount $33-38 \%$ of the total volume of costs.

There is a system in our country that implies the significant amount of extra-budgetary funds in the inland waterway transport sector that are allocated to the construction of a commercial fleet. As for the infrastructure, it is financed mainly by means of budgetary funds. The adopted Strategy slightly extends the usual area of application of extrabudgetary funds: at present, they are planned to be used for the construction and reconstruction of inland waterway infrastructure under the terms of public-private partnership. One of the ten major investment infrastructure water transport projects planned by the Strategy is expected to be implemented using the mechanism of public-private partnership. This project of creating parallel locks for the Volga-Don waterway is vitally important for the preservation of the integrity of the United Deep Water System. The total design costs are 37 billion rubles, which is a fifth of the total planned expenditure for all major investment projects implemented within the framework of the Strategy. The precedent, which will allow using this mechanism within the implementation of investment projects in inland water transportation, will be established by the implementation of this project under the terms of public-private partnership. That is why it is extremely important.

Using the mechanisms of public-private partnership will create a model for the development of the industry that is alternative to traditional mechanisms of public financing, while not allowing the privatization of infrastructure. However, there is no generally accepted concept of such a partnership, this legal institution is not sufficiently studied.

\section{Results}

The analysis of foreign experience revealed that currently existing forms of investing into inland water transport do not allow fully implementing the plans for the development of the 
industry even in such countries as Germany, the United States or China. State financing, which is an integral part of the water transport industry, is sufficient neither for the largest world economy of the USA, nor for growing China or the integrated European Union (hereinafter - the EU).

Moreover, currently the volume of public funds tends to be reducing, which leads to the more active use of alternative sources of financing. In particular, the so-called commercial network of inland waterways of the USA pays the fuel tax. China has adopted this practice as well, so the role of regional financing of water transport infrastructure there has increased in recent years along with the state financing. In the EU, there is a practice of "multi-layer" financing using EU funds, ship fees and even a part of the funds collected from heavy vehicles.

\section{Discussion}

A steady negative tendency of reduce of inland water transport role was observed during last decades in the transport system of Russia. The analysis of the state of the fixed assets of this sector enabled identifying the main issues that restrain its active development and the recoup of lost positions. Table 1 and Table 2 represents the analysis of the value of fixed assets and the degree of the wear of fixed assets of transportation companies [15].

Table 1. Fixes assets if transportation companies, billion rubles (at the end of the year)

\begin{tabular}{lrrrrrr}
\hline \multicolumn{1}{c}{ Indicator } & \multicolumn{1}{c}{2010} & \multicolumn{1}{c}{2011} & \multicolumn{1}{c}{2012} & \multicolumn{1}{c}{2013} & \multicolumn{1}{c}{2014} & \multicolumn{1}{c}{2015} \\
\hline $\begin{array}{l}\text { Transport }- \text { totally } \\
\text { by type of activity }\end{array}$ & $\mathbf{8 6 3 3 . 2}$ & $\mathbf{9 9 7 1 . 6}$ & $\mathbf{1 1 1 2 3 . 9}$ & $\mathbf{1 2 0 5 5 . 2}$ & $\mathbf{1 3 8 5 3 . 5}$ & $\mathbf{1 4 6 6 0 . 5}$ \\
railway transport: & 322.7 & 3712.2 & 3921.1 & 4504.1 & 4562.3 & 4408.2 \\
$\begin{array}{l}\text { automobyle, bus, public } \\
\text { transport under the }\end{array}$ & & & & & & \\
schedule & 76.8 & 88.5 & 95.2 & 124.3 & 252.9 .2 & 164.1 \\
city electric transport & 1148.5 & 1264.8 & 1303.0 & 1368.9 & 1469.7 & 1518.9 \\
road freight transport & 65.9 & 88.4 & 111.4 & 115.8 & 114.1 & 131.0 \\
pipeline transportation & 2523.5 & 3113.2 & 4013.3 & 3975.7 & 4700.1 & 5099.6 \\
sea transport & 62.2 & 59.1 & 57.5 & 65.0 & 72.7 & 88.8 \\
inland waterway transport & 40.7 & 57.6 & 70.1 & 76.7 & 79.2 & 89.9 \\
air transport & 147.2 & 176.8 & 194.9 & 189.0 & 152.1 & 151.9 \\
\hline
\end{tabular}

Thus, the degree the material and technical base ware of inland waterway transport is much higher than the corresponding rate of the transport industry in general. The study showed that the inability of the current system of financing inland water transport to ensure the necessary level of reproduction of fixed assets is one of the main problems hampering the development of shipping.

The development of inland water transport in general occurs in the conditions of shortage of investment resources.

Due to the existing tendency of budget expenditure reduction in the current economic conditions, the amount of state funds allocated for the development of the sector cannot be revised upwards. On the contrary, there is a decrease in the size of the standards of financial costs for the support of the industry. In particular, the deadlines for the transition to full financing of the costs of maintaining inland waterways are postponed. Thus, at the current stage of the industry development, it is necessary to search for additional extra-budgetary sources of investments, which should be implemented using the world experience. Table 3 provides information on the volume of investment by mode of transport [15]. 
Table 2. Wear degree of fixed assets of transportation companies, $\%$

\begin{tabular}{lcccccc}
\hline \multicolumn{1}{c}{ Indicator } & 2010 & 2011 & 2012 & 2013 & 2014 & 2015 \\
\hline $\begin{array}{l}\text { Transport - totally } \\
\text { by type of activity: }\end{array}$ & $\mathbf{3 2 . 9}$ & $\mathbf{3 4 . 7}$ & $\mathbf{3 6 . 0}$ & $\mathbf{3 7 . 6}$ & $\mathbf{3 9 . 6}$ & $\mathbf{4 1 . 1}$ \\
$\begin{array}{l}\text { railway transport } \\
\text { automobyle, bus, public }\end{array}$ & 38.9 & 30.4 & 33.0 & 32.8 & 34.3 & 36.3 \\
$\begin{array}{l}\text { transport under the } \\
\text { schedule }\end{array}$ & & & & & & \\
city electric transport & 52.7 & 55.3 & 56.2 & 55.5 & 55.7 & 59.2 \\
road freight transport & 44.3 & 15.6 & 16.3 & 16.9 & 16.4 & 17.4 \\
pipeline transportation & 48.9 & 42.1 & 45.4 & 44.8 & 47.5 & 48.4 \\
sea transport & 32.1 & 34.7 & 45.2 & 49.3 & 49.1 & 51.2 \\
inland waterway transport & 60.9 & 50.7 & 48.4 & 53.6 & 53.9 & 56.8 \\
air transport & 47.7 & 45.0 & 39.0 & 40.9 & 45.2 & 44.3 \\
\hline
\end{tabular}

Table 3. Investments by main types of transport activity, billion rubles

\begin{tabular}{lrlrrrr}
\hline \multicolumn{1}{c}{ Indicator } & \multicolumn{1}{c}{2010} & \multicolumn{1}{c}{2011} & \multicolumn{1}{c}{2012} & \multicolumn{1}{c}{2013} & \multicolumn{1}{c}{2014} & \multicolumn{1}{c}{2015} \\
\hline $\begin{array}{l}\text { Transport - totally } \\
\text { by type of activity: }\end{array}$ & $\mathbf{1 4 7 1 . 0}$ & $\mathbf{2 0 4 8 . 3}$ & $\mathbf{2 0 6 3 . 6}$ & $\mathbf{1 9 9 9 . 9}$ & $\mathbf{1 8 7 1 . 6}$ & $\mathbf{1 8 6 2 . 5}$ \\
$\begin{array}{l}\text { railway transport } \\
\text { automobyle, bus, public }\end{array}$ & 364.6 & 403.1 & 443.4 & 413.9 & 328.4 & 339.3 \\
$\begin{array}{l}\text { transport under the } \\
\text { schedule }\end{array}$ & & & & & & \\
city electric transport & 12.3 & 18.9 & 16.2 & 24.4 & 12.8 & 11.5 \\
road freight transport & 56.4 & 80.5 & 111.6 & 218.6 & 102.9 & 82.1 \\
pipeline transportation & 62.5 & 19.3 & 25.1 & 28.0 & 18.9 & 20.6 \\
sea transport & 4.6 & 949.9 & 836.2 & 643.0 & 714.6 & 715.4 \\
inland waterway transport & 2.7 & 13.3 & 3.4 & 6.2 & 7.0 & 3.3 \\
air transport & 18.9 & 17.8 & 26.4 & 33.1 & 44.5 & 57.6 \\
\hline
\end{tabular}

Attraction of private investments into transport infrastructure is a common world practice. However, in Russia the imbalance towards state financing is too big. The share of state participation in the financing of transport infrastructure is $84 \%$, which is much higher than in the world economic centers. Further active implementation of the practice of project introduction using public-private partnership mechanisms can change the situation. The work in this direction is being performed now, particularly, the legislation is being improved. For instance, on January 1, 2016, the new Federal Law "On Public-Private Partnership" came into force. Before this, the federal law "On concession agreements" for a long time was the main regulator of the state-business cooperation area.

The new law on public-private partnership provides for the mandatory implementation of a procedure for the technical-and-economical justification of such projects. The industry, despite all the obvious advantages of using various forms of public-private partnership in inland water transport, faces a number of serious obstacles, since such projects are not attractive enough for the private sector. The reason is that investment projects in the field of inland water transport often are characterized by high capital intensity, long payback periods and low profitability. The practice of implementing public-private partnership projects in inland waterway transport may become more attractive for private businesses when 
implementing such projects coupled with introducing user-pays charges. According to the study, the introduction of additional fees will become the factor ensuring the reliability of return on investment, providing an acceptable rate of return for business in the field of water transport, and thus will increase the commercial attractiveness for private capital.

The formula proposed by the authors for determining the navigational fee for the passage of foreign vessels is (1):

$$
\mathrm{Dn}=\mathrm{L} \times \mathrm{N} \times \mathrm{T},
$$

where $\mathrm{Dn}$ is the amount of fees for navigation, million rubles; $\mathrm{N}$ - the value of foreign ship traffic, units of the fleet; $\mathrm{L}$ - length of the route, $\mathrm{km} ; \mathrm{T}$ - tariff rate for ship-km, rubles.

Similarly, the formula of fee for lockage (2):

$$
\mathrm{Ds}=\mathrm{T} \times \mathrm{N},
$$

where Ds is the amount of the fee for navigation lockage; $\mathrm{N}$ is the value of foreign traffic; $\mathrm{T}$ is the fare rate for the ship's lockage.

The system of applying economic measures for the implementation of state policy, which stimulates transportation in vessels of a certain type or supports certain categories of users of infrastructure, is poorly developed in Russia. The state should more actively apply a more flexible tariff policy. When introducing new fees, it is primarily necessary to take into account the situation in the industry in terms of the financial condition of the inland waterway transport enterprises. The organizations involved in the transport of goods are the mast profitable. Passenger transportation is often unprofitable. Taking into account the limited investment opportunities of the industry, one cannot allow a critical reduction of the profitability of water transport organizations when introducing additional fees. Such a situation demands the introduction of fees primarily for foreign vessels.

\section{Conclusions}

The demand in updating the fixed assets of inland waterway transport is one of the most urgent practical issues restraining the development of river navigation in Russia. To change the situation using only a limited amount of allocated budget funds is difficult and sometimes impossible in modern conditions. In order to find additional sources, the rich foreign and domestic experience in investing of transport infrastructure projects was analyzed, including the use of public-private partnership mechanisms.

Measures to improve the legislative base in the field of public-private partnership in transport, as well as mechanisms for assessing the effectiveness of transport projects will help to accelerate the modernization of the industry under the limited budgetary resources and thereby ensure an innovative scenario for the development of the national economy.

A study of the current state of the market for public-private partnership projects in Russia has shown that private investors are not interested in the inland water transport sector because of its high capital intensity and low profitability. The measures of charging fees from users elaborated by the authors are meant to make water transport infrastructure projects more attractive for business. At the same time, proposals on the adaptation of foreign practice of applying a flexible tariff policy to certain categories of our transport fleet as well as recommendations for collecting charges from foreign vessels will help to prevent the worsening of the financial condition of domestic shipping companies.

The opening of the inland waterways of the Russian Federation for foreign vessels within the framework of the "Strategy for the development of inland water transport of the Russian Federation for the period up to 2030", as well as the development of measures for the effective use of inland waterways of the Russian Federation as international communications, 
will increase the passage of international vessels and consequently the amount of collected fees. The targeted use of charges for the modernization of the water transport infrastructure will help the ship owners to receive guarantees of reliable and safe operation due to reduction of the limiting areas, which will ultimately have a positive effect on the economy of the country.

\section{References}

1. A. Belitskaya Legal regulation of public-private partnership (2012)

2. S. E. Litovchenko, M.I. Korsakova, Corporate social responsibility: public expectations (2003)

3. V. G. Varnavsky, A. V. Klymenko, Public-private partnership: theory and practice (2010)

4. R. Kachalov Economic risk Management-the basis of economic security of the region (2006)

5. V. Reznichenko Risk management (2004)

6. E. Voskresenskaya, et.al. MATEC Web of Conferences 10608055 (2017)

7. E. Voskresenskaya, V. Snetkov and A. Tebryaev E3S Web of Conferences 33, 03051 (2018) doi.org/10.1051/e3sconf/20183303051

8. E. Voskresenskaya and L. Vorona-Slivinskaya V E3S Web of Conferences 33, 03052 (2018) https://doi.org/10.1051/e3sconf/20183303052

9. E. Voskresenskaya, D. Mokhorov and A. Tebryaev 170, 01058 (2018) DOI https://doi.org/10.1051/matecconf/201817001058

10. E. Voskresenskaya, et.al. MATEC $\mathbf{1 7 0} 01057 \quad$ (2018) DOI https://doi.org/10.1051/matecconf/201817001057

11. P. K. Sun, L.Vorona-Slivinskaya, E. Voskresenskaya IOP Conference Series: Earth and Environmental Science 90 (2017) https://doi.org/10.1088/1755-1315/90/1/012073

12. E. Voskresenskaya, et.al. MATEC Web of Conferences, 193, 02025 (2018) doi.org/10.1051/matecconf/201819302025

13. E. Voskresenskaya, et.al. Constitutional-legal issues of ensuring environmental safety in modern Russia 8 (19), 57-59 (2018)

14. E. Voskresenskaya, Economic and legal problems devastated territories in the russian federation 7 (18), 62-65 (2018)

15. A. Mottaeva, J. Ćetković Advances in Intelligent Systems and Computing, 692, 1151 1159 (2018) doi: 10.1007/978-3-319-70987-1_123

16. A. Mottaeva, IOP Conf. Series: Earth and Environmental Science, 90, 012124 (2017) doi :10.1088/1755-1315/90/1/012124

17. T. Tereshkina, A. Mottaeva, L. Andreeva, T. Larinina, IOP Conf. Series: Earth and Environmental Science, 90, 012138 (2017) doi:10.1088/1755-1315/90/1/012138 